Her view represents in general a refreshing change from recently fashionable reductionist approaches. It is not irrefutable but, as K.R. Popper properly understood, what worthwhile hypothesis is? Dr Ross puts forward her more speculative suggestions with caution, and where she disagrees with others, does so with characteristic courtesy. Her book is written in an elegant style. Without loss of intellectual rigour, it reaches out to all who may be interested in its subject. It is also a handsome piece of book pro- duction. Illustrations, of subjects both familiar and unique, are of high quality. Richard Feachem's drawings and maps are beautiful and lucid.

DAVID RANKIN

University of Southampton

\section{References}

CHADWICK, N.K. 1966. The Druids. Gardiff: University of Wales. KENDRICK, T.D. 1925. The druids: a study in Keltic prehistory. London: Methuen.

PIGGotr, S, 1968. The Druids, London: Thames \& Hudson.

\title{
Editorial and subscription notices
}

ANTIQUITY, founded in 1927 by O.G.S. Crawford, is owned by the Antiquity Trust, a registered charity.

The Trustees of The Antiquity Trust are: Warwick Bray, John Coles, Barry Cunliffe, Anthony Harding, Paul Mellars, Lord Renfrew, Stephen Shennan, Sir David Wilson. The directors of Antiquity Publications Ltd, owned by The Antiquity Trust and responsible for producing ANTIQUITY, are: Caroline Malone, Joan Oates, Andrew Rogerson, Richard Skaer, Anthony Snodgrass.

\section{Current subscriptions}

ANTIQUITY is published every three months, on 1 March, 1 June, 1 September and 1 December.

For 2000 the annual subscription is:

$\begin{array}{lll}\text { UK \& Europe } & \text { institutional } & \text { personal } \\ \text { USA and rest of world } & £ 65 / € 110 & £ 35 / € 55 \\ \$ 115^{*} & \$ 66\end{array}$

* with a special third-world institutional rate of $£ 35$ \& $\$ 66$.

For 2000 the annual special reduced student subscription, valid for two years after completion of course, is:

UK \& Europe $\quad £ 23 / € 35$

USA and rest of world $\$ 44$

The optional annual airmail surcharge is: $\$ 20 / £ 11 / € 15$ (Institutions (Full)) and

$£ 17 / £ 10 / € 14$ (other categories)

Subscriptions are payable annually in advance to:

Subscriptions Department, The Company of Biologists, Bidder Building, 140 Cowley Road, Cambridge CB4 4DL, England; phone (44)-1223-426164; FAX (44)1223-423353; e-mail sales@biologists.com who accept payment by cheque, bank draft, money order or credit card.

\section{Subscribers' address changes}

Subscribers send changes to: Subscriptions Department, The Company of Biologists, Bidder Building, 140 Cowley Road, Cambridge CB4 4DL, England.
Postmaster send changes to Antiquity, c/o Mercury Airfreight International Ltd, 2323 Randolph Avenue, Avenel NJ 07001, USA.

\section{Current single issues and back-numbers}

Single copies of 1999 issues and of recent back-numbers, volume 67 (1993) to volume 71 (1997), cost:

UK \& Europe $\quad £ 22 / € 35 \quad £ 12 / € 20$

USA and rest of world $\$ 38^{*} \quad \$ 22$

${ }^{*}$ with a special third-world institutional rate of $£ 12$ $\& \$ 22$.

Older back-numbers are available from: Dawson's Back Issues, Canon House, Park Farm Road, Folkestone CT19 5EE, England.

Some older back-numbers, also the index to vols. 51-65 for 1977-91, are also available direct from ANTIQUITY.

\section{Editorial address}

ANTIQUiTY, New Hall, Cambridge CB3 ODF, England is the address for all matters - editorial, reviews, advertising, financial - except for subscriptions (which go to The Company of Biologists, as above).

Editorial matters are handled by the Editor, Caroline Malone, and Deputy Editor, Simon Stoddart; the review section by the reviews editor, Nicholas James; advertising, back-numbers and internet by the editor's assistant, Libby Peachey, and production by the production editor, Anne Chippindale fall telephone (44)-1223-762298; FAX/messages (44)-1223$357075]$.

ANTIQUITY's e-mail address is catm20@cam.ac.uk and its web-page is at http://intarch.ac.uk/antiquity/

\section{Advertising}

Please write to: Libby Peachey, Antiquity, New Hall, Cambridge CB3 ODF, England [telephone (44)-1223762298; FAX/messages (44)-1223-357075]. 


\section{Advisory editors for the 1999 volume}

David Anthony (Oneonta) (Central Asia, palaeoeconomy, Bronze Age, horses)

anthonyD@hartwick.edu

Paul Bahn (UK) (rock-art, Palaeolithic, Easter Island) pgbahn@anlabyrd.karoo.co.uk

Mike Blake (Vancouver) (Mesomerica, Canada) mblake@unixg.ubc.ca

Robin Coningham (Bradford) (South Asia, Sri Lanka)

R.A.E.Coningham@bradford.ac.uk

Tim Darvill (Bournemouth) (landscape, prehistory, CRM, Russia) tdarvill@athena.bournemouth.ac.uk Ian Freestone (British Museum) (archaeological science, conservation) IFreestone@british-museum.ac.uk Alessandro Guidi (Verona) (Mediterranean archaeology, especially Italy, protohistory, archaeological theory) aguidi@chiostro.univr.it

Norman Hammond (Boston) (Central antt South

America, media archaeology) ndch@bu.edu

Heinrich Härke (from October 1998) (Reading) (theory, northern Europe, Iron Age-medieval]

h.g.h.harke@reading.ac.uk

Fekri Hassan (UCL) (population, north Africa-west Asia, prehistory, Egypt) f.hassan@ucl.ac.uk

Charles Higham (Otago) (New Zealand, Southeast

Asia) charles.higham@stonebow.otago.ac.nz

Paul Lane (BIEA-Nairobi) (Africa, later prehistory)

pjlane@insightkenya.com

David Mattingly (Leicester) (Roman world, north

Africa and Italy djm7@leicester.ac.uk

Roger Mercer (RCHMS Edinburgh) (European prehistory, Scotland, CRM)
Lynda Mulvin (UC Dublin) (Roman art \& archaeology, Balkans, stone conservation and Ireland) LMulvin@macollamh.ucd.ie

Sebastian Payne (English Heritage) (archaeology, science, zooarchaeology, Turkey) spayne@eng-h.gov.uk

Susan Pollock (SUNY Binghamton) (Middle East, complex society, archaeology \& politics) bg9711@binghamton.edu.

Jessica Rawson (Oxford) (China, Asia)

Andrew Sherratt (Later European prehistory, world systems, theory) andrew.sherratt@ashmus.ox.ac.uk Chris Stringer (BM-NH, London) (early man, evoIution) c.stringer@nhm.ac.uk

Ezra Zubrow (SUNY Buffalo) (North America, theory, population, Palaeolithic)

zubrow@zubrowsun.anthro.buffalo.edu

ISSN $0003598 \mathrm{X}$

Set in Linotron Melior

Printed and bound in Great Britain

(C) Antiquity Publications 1999. All rights reserved; no part of this publication may be reproduced, stored in a retrieval system, or transmitted in any form or by any means, electronic, mechanical, photocopying, recording, or otherwise without either the prior written permission of the Publishers or a licence permitting restricted copying issued in the UK by the Copyright Licensing Agency Ltd, 90 Tottenham Court Road, London W1P 9JP, or in the USA by the Copyright Clearance Center, 27 Congress Street, Salem MA 01970. 